\title{
Microbial Conversion of EM574 and EM523, Gastrointestinal Motor Stimulating Agents
}

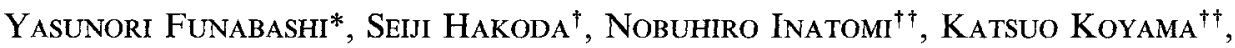 \\ SeIIChI TAnida and Setsuo HaRada ${ }^{\dagger \dagger}$ \\ Discovery Research Division, Takeda Chemical Industries, Ltd., \\ 10 Wadai, Tsukuba, Ibaraki 300-42, Japan \\ ${ }^{\dagger}$ Intellectual Property Department, ${ }^{\dagger \dagger}$ Pharmaceutical Research Division, \\ Takeda Chemical Industries, Ltd., \\ 2-17-85 Juso-honmachi, Yodogawa-ku, Osaka 532, Japan
}

\section{ZEN ITOH}

GI Laboratory, Institute for Molecular and Cellular Regulation, Gunma University, Maebashi, Gunma 371, Japan

\section{SATOSHI ŌMURA}

The Kitasato Institute,

5-9-1 Shirokane, Minato-ku, Tokyo 108, Japan

(Received for publication March 6, 1996)

\begin{abstract}
EM574 exerts gastrointestinal motor stimulating (GMS) activity even after being converted to its metabolites P1 and P2 in dogs. These metabolites were isolated from dog liver using a series of chromatographic procedures. Their structures were determined to be the 15- and 14-hydroxyl derivatives of EM574, respectively, by spectral analysis.

Large scale preparation by microbial transformation was investigated for further evaluation of the metabolites, because the amounts obtained by oxidation with dog liver homogenate were limited. Three strains of actinomycetes, Amycolatopsis tolypophorus IFO 13151, Dactylosporangium variesporum IFO 14104 and Nocardia capreola IFO 12847, were found to have the aiming oxidative potency. HPLC analysis of the crude extracts from these three cultures showed that the bioactive metabolites, EM574 P1 and P2 were produced. They were isolated from the culture broth with the other bioactive products EM574 P3 and P4. These bioactive products were prepared by large scale cultivation. EM574 P3 and P4 showed GMS activity comparable to that of EM574 P1 and P2.

The structures of EM574 P3 and P4 were elucidated by spectral analysis and found to be the 3"-O-demethyl derivatives of EM574 P2 and EM574, respectively. Moreover, the absolute configuration at the $\mathrm{C} 14$ position of $\mathrm{P} 2$ was determined to be $\mathrm{R}$ by spectral analysis of the 6 -membered cyclic carbonate of EM574 P2.
\end{abstract}

Erythromycin (EM) has been recognized to have prokinetic activities in addition to antibacterial activities. Its action resembles that of a gastrointestinal hormone, motilin. ${ }^{1}{ }^{4)}$ Recent findings have provided evidence that EM is a motilin receptor agonist. ${ }^{5 \sim 7)}$ Accordingly, these evidences shed light on EM derivatives as promising new prokinetic drugs. Investigations on EM derivatives developed two motilides, EM574 (1) and EM523 (2), which showed stronger gastrointestinal motor stimulating (GMS) activity than EM A without antibacterial activities. ${ }^{89}$ However, the plasma levels of the agents were very low upon oral or intraduodenal administration in dogs and all of proposed metabolites did not have enough activity to explain the strong activity. These observations suggested that unknown "bioactive metabo- lites" might be responsible for the GMS activity.

Two bioactive metabolites, $\mathrm{P} 1$ and $\mathrm{P} 2$, were isolated from dog liver by chromatographic procedures as detected by contractile activity using an isolated rabbit duodenum. Their structures were determined to be the 15- and 14-hydroxyl derivatives of the parent compounds, respectively, by spectral analysis. Preparation of the metabolites was accomplished by oxidation with dog liver homogenates, but only limited quantities were obtained. ${ }^{10)}$ For pharmaceutical and pharmacokinetic studies and further chemical characterization, much larger amounts of the metabolites were necessary. Chemical modification to prepare the 15- and 14hydroxyl derivatives seemed to be next to impossible without using partial synthetic methods. Thus, we 
Fig. 1. Structures of EM574, EM523 and their metabolites.

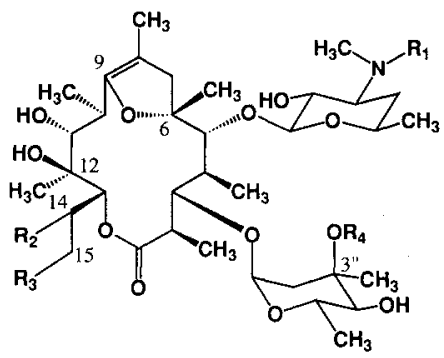

\begin{tabular}{lcccc}
\hline Compound & $\mathrm{R}_{1}$ & $\mathbf{R}_{2}$ & $\mathrm{R}_{3}$ & $\mathrm{R}_{4}$ \\
\hline EM574 (1) & i-Pr & $\mathrm{H}$ & $\mathrm{H}$ & $\mathrm{CH}_{3}$ \\
EM523 (2) & Et & $\mathrm{H}$ & $\mathrm{H}$ & $\mathrm{CH}_{3}$ \\
EM574 P1 (3) & i-Pr & $\mathrm{H}$ & $\mathrm{OH}$ & $\mathrm{CH}_{3}$ \\
EM574 P2 (4) & i-Pr & $\mathrm{OH}$ & $\mathbf{H}$ & $\mathrm{CH}_{3}$ \\
EM523 P1 (5) & Et & $\mathrm{H}$ & $\mathrm{OH}$ & $\mathrm{CH}_{3}$ \\
EM523 P2 (6) & Et & $\mathrm{OH}$ & $\mathrm{H}$ & $\mathrm{CH}_{3}$ \\
EM574 P3 (7) & i-Pr & OH & $\mathrm{H}$ & $\mathrm{H}$ \\
EM574 P4 (8) & i-Pr & $\mathrm{H}$ & $\mathrm{H}$ & $\mathrm{H}$ \\
EM523 P3 (9) & Et & $\mathrm{OH}$ & $\mathrm{H}$ & $\mathrm{H}$ \\
\hline
\end{tabular}

examined microbial conversion to produce these metabolites more efficiently. A part of this paper has been orally reported. ${ }^{11)}$

\section{Results}

Preparation of the Metabolites P1 and P2 by Microbial Conversion

Eleven strains of actinomycetes stored at Institute for Fermentation, Osaka were selected and tested for their potency to consume 1 . They were cultured at $28^{\circ} \mathrm{C}$ for 24 hours. Lactobionate of $1(1 \mathrm{~L}$, final conc. $100 \mu \mathrm{g} / \mathrm{ml})$ was then added followed by incubation for another 24 hours. The supernatant was extracted with ethyl acetate to give a crude extract. The remaining 1 in the extract was estimated by HPLC analysis (ODS, $37 \%$ acetonitrile $-0.02 \mathrm{M}$ phosphate buffer; $\mathrm{pH} 4.0=$ solvent A) as listed in Table 1. The results indicated that 1 was consumed by three strains of actinomycetes, Amycolatopsis tolypophorus IFO 13151, Dactylosporangium variesporum IFO 14104 and Nocardia capreola IFO 12847. The presence of EM574 P1 (3) or P2 (4) was determined by HPLC (ODS, 32\% acetonitrile $-0.02 \mathrm{M}$ phosphate buffer; $\mathrm{pH} 4.0=$ solvent B) of the crude extracts derived from these three strains. A.tolypophorus and $D$. variesporum were found to produce 4 , and $N$. capreola was found to produce both 3 and 4 .

In the case of $N$. capreola, the optimal incubation period was found to be $4 \sim 6$ hours after the addition of
Table 1. Metabolism of EM574 by actinomycetes.

\begin{tabular}{|c|c|c|c|c|}
\hline Strain & $\begin{array}{l}\text { IFO } \\
\text { No. }\end{array}$ & $\mathrm{pH}$ & Growth & $\begin{array}{l}\text { Residual } \\
\text { rate (\%) }\end{array}$ \\
\hline Actinoplanes azureus & 13993 & 6.8 & \pm & 119.6 \\
\hline Actinoplanes caeruleus & 13939 & 7.3 & ++ & 97.0 \\
\hline Amycolatopsis mediterranei & 13415 & 8.5 & +++ & 61.8 \\
\hline tolypophorus & 13151 & 8.1 & + & 0.0 \\
\hline $\begin{array}{c}\text { Dactylosporangium } \\
\text { variesporum }\end{array}$ & 14104 & 8.6 & ++ & 2.9 \\
\hline Nocardia capreola & 12847 & 8.1 & $++t$ & 0.0 \\
\hline Saccharothrix australiensis & 14444 & 8.8 & +++ & 53.9 \\
\hline Streptomyces griseobrunneus & 12775 & 8.4 & $+t+$ & 48.0 \\
\hline Streptomyces lactamdurans & 13305 & 8.6 & +++ & 78.4 \\
\hline Streptomyces nigrescens & 12894 & 5.8 & $++t$ & 90.2 \\
\hline Streptomyces violaceoruber & 12826 & 7.0 & ++ & 48.0 \\
\hline
\end{tabular}

1. The seed culture was transferred to the media and incubated at $28^{\circ} \mathrm{C}$ for 24 hours. The culture broth thus obtained was mixed with $1 \mathrm{~L}$ followed by incubation for 6 hours. The broth was purified according to the procedure ${ }^{10}$ for the isolation of $\mathbf{3}$ and $\mathbf{4}$ from the liver homogenate to give a crude powder. This was subjected to silica gel chromatography to afford crude powders of 3 and 4, respectively. These were purified by preparative HPLC (ODS, methanol or acetonitrile in phosphate buffer; $\mathrm{pH} 4.0$ ) to give 3 and $\mathbf{4}$, respectively. As a result, 3 and 4 (total yield $9.5 \%$ ) were isolated from the culture broth of $N$. capreola.

In the case of $D$. variesporum, the optimal incubation period was found to be 24 hours after the addition of $\mathbf{1}$. The cultivation and isolation were carried out in the same procedure as in the case of $N$. capreola. From the broth, 4 (yield $3.0 \%$ ) was isolated. In the case of A. tolypophorus, the optimal incubation period was found to be 20 hours after the addition of 1 . From the broth of A.tolypophorus, 4 (yield 20\%) was isolated.

The Unique Metabolites in Microbial Conversion

Prokaryotes, such as bacteria and actinomycetes, possibly have a metabolic system different from that of eukaryotes, such as fungi and mammals. For example, in the oxidative metabolism by cytochrome P450, the former demands $\mathrm{NAD},{ }^{12)}$ the latter requires NADP. Therefore, actinomycetes might convert 1 to unique metabolites of their own. The metabolic products of the three strains were subjected to preparative HPLC (ODS, solvent B). All the fractions were subjected to the contraction assay. ${ }^{10)}$

The products of $A$. tolypophorus gave no bioactive fraction but that of 4 . On the other hand, the extracts from $D$. variesporum contained bioactive fractions at 
Table 2. Microbial conversion of EM574/523 by actinomycetes.

\begin{tabular}{|c|c|c|c|c|c|}
\hline $\begin{array}{l}\text { Broth } \\
\text { (liter) }\end{array}$ & $\begin{array}{l}\text { Substrate } \\
\text { (g) }\end{array}$ & $\begin{array}{c}\text { P1 (mg) } \\
(\%)\end{array}$ & $\begin{array}{c}\mathrm{P} 2(\mathrm{mg}) \\
(\%)\end{array}$ & $\begin{array}{c}\mathrm{P} 3(\mathrm{mg}) \\
(\%)\end{array}$ & $\begin{array}{c}\text { P4 (mg) } \\
(\%)\end{array}$ \\
\hline \multicolumn{6}{|c|}{ Nocardia capreola } \\
\hline 3 & $0.5(1)$ & $4(0.8)$ & $43(8.4)$ & - & - \\
\hline 120 & $12.0(1)$ & $105(0.9)$ & $338(2.8)$ & $76(0.6)$ & - \\
\hline 120 & $12.0(\mathbf{1})$ & $149(1.2)$ & $1.4 \mathrm{~g} \mathrm{(11.4)}$ & $95(0.8)$ & - \\
\hline 1200 & $120.0(1)$ & $1.0 \mathrm{~g}(0.8)$ & $13.2 \mathrm{~g}(10.8)$ & $3.3 \mathrm{~g} \mathrm{(2.7)}$ & - \\
\hline 120 & $12.0(2)$ & $15(0.1)$ & $812(6.8)$ & $200(1.7)$ & - \\
\hline 120 & $12.0(2)$ & $14(0.1)$ & $4.1 \mathrm{~g}(34.0)$ & $194(1.6)$ & - \\
\hline \multicolumn{6}{|c|}{ Dactylosporangium variesporum } \\
\hline 10 & $1.0(\mathbf{1})$ & - & $42(4.1)$ & $46(4.6)$ & $49(5.0)$ \\
\hline 120 & $12.0(1)$ & - & $104(0.8)$ & $129(1.1)$ & $133(1.1)$ \\
\hline 120 & $12.0(2)$ & - & - & $383(3.2)$ & - \\
\hline \multicolumn{6}{|c|}{ Amycolatopsis tolypophorus } \\
\hline 3 & $0.5(1)$ & - & $102(20.0)$ & - & - \\
\hline
\end{tabular}

-: Not detected.

Table 3. ${ }^{13} \mathrm{C}$ NMR data for EM574, EM523 and their metabolites.

\begin{tabular}{|c|c|c|c|c|c|c|c|c|c|}
\hline C-No. & 1 & 2 & 3 & 4 & 5 & 6 & 7 & 8 & 9 \\
\hline 1 & 178.4 & 178.4 & 178.6 & 177.5 & 178.8 & 177.5 & 177.2 & 178.2 & 177.2 \\
\hline 2 & 44.8 & 44.8 & 44.2 & 44.5 & 44.2 & 44.6 & 44.7 & 45.0 & 44.6 \\
\hline 3 & 76.5 & 76.3 & 75.9 & 75.9 & 75.0 & 76.3 & 76.4 & 76.5 & 76.3 \\
\hline 4 & 43.4 & 43.5 & 43.7 & 43.6 & 43.7 & 43.5 & 43.5 & 43.3 & 43.6 \\
\hline 5 & 80.2 & 80.1 & 79.8 & 79.9 & 79.8 & 80.1 & 80.1 & 80.4 & 79.9 \\
\hline 6 & 85.6 & 85.6 & 85.6 & 85.8 & 85.7 & 85.8 & 86.1 & 86.0 & 86.1 \\
\hline 7 & 42.7 & 42.6 & 42.5 & 42.6 & 42.5 & 42.6 & 42.8 & 42.8 & 42.7 \\
\hline 8 & 101.6 & 101.6 & 101.7 & 101.9 & 101.7 & 102.0 & 102.3 & 101.9 & 102.2 \\
\hline 9 & 151.7 & 151.7 & 151.8 & 151.3 & 151.8 & 151.2 & 151.1 & 151.5 & 151.2 \\
\hline 10 & 30.5 & 30.5 & 30.6 & 30.5 & 30.6 & 30.4 & 30.5 & 30.5 & 30.6 \\
\hline 11 & 70.2 & 70.0 & 70.1 & 69.5 & 70.2 & 69.9 & 69.8 & 70.2 & 69.7 \\
\hline 12 & 75.4 & 75.4 & 74.9 & 77.6 & 74.9 & 75.4 & ND & 75.4 & 77.2 \\
\hline 13 & 78.3 & 78.3 & 74.6 & 75.9 & 74.6 & 72.1 & 75.9 & 78.4 & 76.0 \\
\hline 14 & 21.1 & 21.1 & 31.3 & 66.4 & 31.3 & 66.4 & 66.3 & 21.0 & 66.4 \\
\hline 15 & 10.9 & 10.9 & 59.2 & 20.0 & 59.2 & 20.0 & 20.0 & 10.9 & 19.9 \\
\hline 2-Me & 13.5 & 13.4 & 12.7 & 13.1 & 12.8 & 13.3 & 13.2 & 13.6 & 13.0 \\
\hline 4-Me & 8.7 & 8.7 & 8.8 & 8.6 & 8.8 & 8.6 & 8.4 & 8.5 & 8.4 \\
\hline $6-\mathrm{Me}$ & 26.3 & 26.3 & 26.5 & 26.2 & 26.5 & 26.2 & 25.9 & 26.0 & 25.9 \\
\hline 8-Me & 12.0 & 12.0 & 11.9 & 12.0 & 11.9 & 12.0 & 12.0 & 11.9 & 12.0 \\
\hline $10-\mathrm{Me}$ & 15.0 & 15.1 & 14.9 & 15.3 & 14.8 & 15.2 & 15.5 & 15.2 & 15.6 \\
\hline 12-Me & 16.2 & 16.1 & 16.4 & 16.7 & 16.4 & 16.6 & 16.6 & 16.1 & 16.8 \\
\hline $\mathrm{l}^{\prime}$ & 103.1 & 103.1 & 103.0 & 103.2 & 103.0 & 103.1 & 104.0 & 104.1 & 104.0 \\
\hline $2^{\prime}$ & 70.3 & 70.4 & 70.1 & 70.2 & 70.3 & 70.3 & 70.1 & 70.2 & 70.3 \\
\hline $3^{\prime}$ & 63.1 & 65.2 & 63.1 & 63.1 & 65.1 & 65.2 & 63.1 & 63.1 & 65.0 \\
\hline $4^{\prime}$ & 33.2 & 29.6 & 33.1 & 33.1 & 29.6 & 29.7 & 33.2 & 33.2 & 29.5 \\
\hline $5^{\prime}$ & 68.9 & 69.0 & 68.9 & 69.0 & 69.0 & 69.0 & 69.4 & 69.4 & 69.6 \\
\hline $6^{\prime}$ & 21.4 & 21.4 & 21.4 & 21.4 & 21.4 & 21.3 & 21.4 & 21.4 & 21.4 \\
\hline $\mathrm{N}-\mathrm{Me}$ & 30.9 & 36.3 & 30.9 & 30.9 & 36.3 & 36.3 & 30.9 & 30.6 & 36.2 \\
\hline \multirow[t]{3}{*}{ N-R } & 52.7 & 47.6 & 52.8 & 52.8 & 47.7 & 47.7 & 53.0 & 52.8 & 47.5 \\
\hline & 21.1 & 13.9 & 21.1 & 21.1 & 13.8 & 14.4 & 20.6 & 20.7 & 13.9 \\
\hline & 20.6 & - & 20.5 & 20.5 & - & - & 20.4 & 20.5 & - \\
\hline $1^{\prime \prime}$ & 94.6 & 94.6 & 94.5 & 94.5 & 94.5 & 94.6 & 96.3 & 96.6 & 96.2 \\
\hline $2^{\prime \prime}$ & 34.7 & 34.6 & 34.6 & 34.6 & 34.6 & 34.6 & 40.2 & 40.3 & 40.2 \\
\hline $3^{\prime \prime}$ & 73.1 & 73.0 & 73.1 & 73.1 & 73.1 & 73.0 & ND & 69.8 & 69.8 \\
\hline $4^{\prime \prime}$ & 78.2 & 78.1 & 78.0 & 78.0 & 78.0 & 78.1 & 77.2 & 77.2 & 76.3 \\
\hline $5^{\prime \prime}$ & 65.7 & 65.7 & 65.9 & 65.8 & 65.9 & 65.8 & 66.8 & 66.8 & 66.9 \\
\hline $6^{\prime \prime}$ & 18.2 & 18.2 & 18.1 & 18.1 & 18.1 & 18.2 & 18.1 & 18.2 & 18.1 \\
\hline $7^{\prime \prime}$ & 21.6 & 21.6 & 21.6 & 21.6 & 21.6 & 21.6 & 22.7 & 25.6 & 25.6 \\
\hline $\mathrm{O}-\mathrm{Me}$ & 49.5 & 49.6 & 49.6 & 49.6 & 49.6 & 49.6 & - & - & - \\
\hline
\end{tabular}

ND: Not detected.

$\delta \mathrm{ppm}, \mathrm{CDCl}_{3}, 75 \mathrm{MHz}$ 
retention times $(\mathrm{Rt}) 5 \sim 6$ and $13 \sim 14$ minutes along with that of 4 (Rt $7 \sim 8$ minutes). The conversion mixture of $N$. capreola contained a bioactive fraction at Rt $5 \sim 6$ minutes accompanied by those of 3 and 4 . On analytical HPLC (ODS, solvent B) with detection by UV absorption at $214 \mathrm{~nm}$, the unknown bioactive fractions corresponded to the peaks at Rt 5.3 and 14.0 minutes. They were designated EM574 P3 (7) and P4 (8), and purified by silica gel and preparative HPLC (ODS) from the crude extracts of the two strains. From the culture broth of D. variesporum (mentioned above) 7 and $\mathbf{8}$ were obtained as white powders along with 4 (total yield $9.0 \%$ ). In that of $N$. capreola (mentioned above) 7 was detected, along with 3 and 4 . Substrate 2 was converted by $N$. capreola and analyzed in the same manner as described above. EM523 P1 (5), EM523 P2 (6) and EM523 P3 (9) were detected in the crude extract by HPLC analysis.

Preparation of the Metabolites in Large Scale Cultivation

The production process described above was carried out on a large scale with a 200 -liter fermenter. In this case, the substrate was supplied as an $80 \%$ ethanol solution. The crude products were purified by combinations of silica gel and HP-20 chromatography and preparative HPLC (ODS). As a result, from the culture broth of D. variesporum, 4,7 and 8 (total yield ca. 3\%) were obtained. From that of N. capreola, 3, 4 and 7 were obtained in a $c a .4 \%$ yield totally. From that of $N$. capreola fed on 2, 5, 6 and 9 were obtained in a $c a$. $8.5 \%$ yield totally. However, in the culture mixture of D. variesporum fed on 2, 6 and 9 were produced but not EM523 P4. Yields of the products in these cultures are summarized in Table 2.

The Structures of $\mathrm{P} 3$ and $\mathrm{P} 4$

In the NMR spectra, 7 and 8 showed no $3 "-O$-methyl signal. Along with this, the chemical shifts of $\mathrm{C}^{\prime \prime}, \mathrm{C} 2$ " and $\mathrm{C}^{\prime \prime}$ changed by $2 \sim 6 \mathrm{ppm}$ in the ${ }^{13} \mathrm{C}$ NMR spectra. Apart from these changes, the other signals of 7 and 8 were nearly the same as those of $\mathbf{4}$ and $\mathbf{1}$, respectively. The UV and IR spectra of $\mathbf{7}$ and $\mathbf{8}$ were very similar to those of 1 . The molecular ion peaks $\left(\mathrm{MH}^{+}\right)$of $\mathbf{7}$ and $\mathbf{8}$ were detected at 730 and 746, respectively, in the SI-MS, indicating that they decreased from those of $\mathbf{4}$ and $\mathbf{1}$ by 14 mass units (corresponding to one $\mathrm{CH}_{2}$ ). Therefore, 7 and 8 were concluded to be the $3^{\prime \prime}-O$-demethyl derivatives of $\mathbf{4}$ and $\mathbf{1}$, respectively. The structure of 9 was determined to be the $3^{\prime \prime}$-O-demethyl derivative of 6 in the same way. The structures are shown in Fig. 1, and the ${ }^{13} \mathrm{C}$ NMR spectral data for all the bioactive metabolites and the substrates are listed in Table 3.

\section{Absolute Configuration at the $\mathrm{C} 14$ Position of $\mathrm{P} 2$}

The structures of P1, P2, P3 and P4 were determined except for the absolute configuration at the $\mathrm{C} 14$ position of $\mathrm{P} 2$ and P3. Even with the intensive NMR spectroscopic analysis of 4 , the configuration at the position remained uncertain. Being overlapped by other signals, the 14-H signal could not be distinguished from the others in the NOE experiment. Therefore, 4 was converted to corresponding 6-membered cyclic carbonate.

Erythromycin $\mathrm{A}$ has three $\left(\mathrm{C} 11, \mathrm{C} 2{ }^{\prime}\right.$ and $\left.\mathrm{C}^{\prime \prime}\right)$ secondary and two (C6 and $\mathrm{C} 12)$ tertiary hydroxyl $(\mathrm{OH})$ groups. In the reaction with acid anhydride, $2^{\prime}-\mathrm{OH}$ reacts first, $4^{\prime \prime}-\mathrm{OH}$ second and then 11-OH follows. ${ }^{13)}$ The tertiary $\mathrm{OH}$ groups are expected to react very slowly. Compound 4 has a secondary $\mathrm{OH}$ at $\mathrm{C} 14$ instead of 6-OH. In the reaction of 4 with an excess of 1,1'carbonyldiimidazole (CDI), $2{ }^{\prime}$ - and $4^{\prime \prime}-\mathrm{OH}$ are expected to be easily carbamated. There are two possibilities that a cyclic carbonate is formed over $\mathrm{C} 11 \sim \mathrm{C} 12$ (5-membered ring) or $\mathrm{C} 12 \sim \mathrm{C} 14$ (6-membered ring), and the remaining $\mathrm{OH}(14-\mathrm{OH}$ or $11-\mathrm{OH})$ is to be carbamated. Compound 4 was heated at $80^{\circ} \mathrm{C}$ in toluene with 5 equivalents of CDI for 18 hours affording the two main products $4 \mathbf{4 a}$ and $\mathbf{4 b}$. The physico-chemical (especially NMR) data showed that they have two imidazinocarbonyl groups and one cyclic carbonate group. Both $4 a$ and $4 \mathbf{b}$ have $4^{\prime \prime}$-carbamate and $2^{\prime}-\mathrm{OH}$ groups $\left(2^{\prime}-\mathrm{H}, \delta 3.17\right.$ and $3.16 \mathrm{ppm})$. The $2^{\prime}$-carbamate seems so unstable as to have been hydrolyzed during the work up. When $4^{\prime \prime}-\mathrm{OH}$ of 4 was converted to $4^{\prime \prime}$-carbamate $\mathbf{4 a}$ and $\mathbf{4 b}$, the chemical shifts of $\mathrm{C} 4^{\prime \prime}$ and 4 "-H showed downfield shifts from $\delta_{\mathrm{C}}$ 78.0 and $\delta_{\mathrm{H}} 3.06$ to $\delta_{\mathrm{C}} 83.4$ and $\delta_{\mathrm{H}} 4.88(4 \mathrm{a})$ and to $\delta_{\mathrm{C}}$ 83.3 and $\delta_{\mathrm{H}} 4.81 \mathrm{ppm}(\mathbf{4 b})$. In the ${ }^{1} \mathrm{H}$ NMR spectra of $\mathbf{4 a}$, the $11-\mathrm{H}$ was observed at $\delta 5.30 \mathrm{ppm}$, showing a $1.88 \mathrm{ppm}$ downfield shift from $\delta 3.42 \mathrm{ppm}$, while $14-\mathrm{H}$ was at $\delta 4.46 \mathrm{ppm}$ showing only a $0.36 \mathrm{ppm}$ downfield shift from $\delta 4.10 \mathrm{ppm}$. This indicated that $11-\mathrm{OH}$ was converted to 11-carbamate and the cyclic carbonate was formed over $\mathrm{Cl} 2$ and $\mathrm{C} 14$. On the other hand, $4 \mathrm{~b}$ showed $14-\mathrm{H}$ at $\delta 5.51 \mathrm{ppm}$ and $11-\mathrm{H}$ at $\delta 4.23 \mathrm{ppm}$ indicating that $14-\mathrm{OH}$ was substituted by the carbamate and the carbonate was formed over $\mathrm{C} 11$ and $\mathrm{C} 12$. The structures of $4 a$ and $4 b$ are illustrated in Fig. 2. As for the reactivity in the acylation reaction, the 14-hydroxyl group of 4 seems as reactive as the 11-hydroxyl group.

Concerning the determination of the configuration at C14, information from the NMR data of $\mathbf{4 a}$ was very 
Fig. 2. Cyclic carbonylation of EM574 P2 (4) with carbonyldiimidazole (CDI).

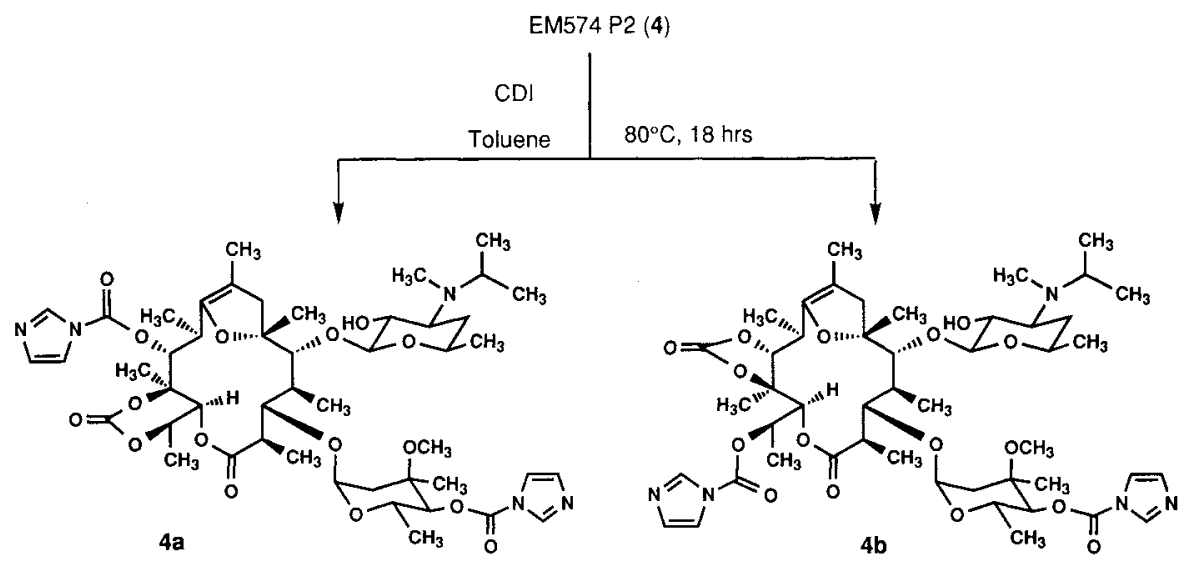

Fig. 3. Determination of the absolute configuration at the C14 position of $4 a$.

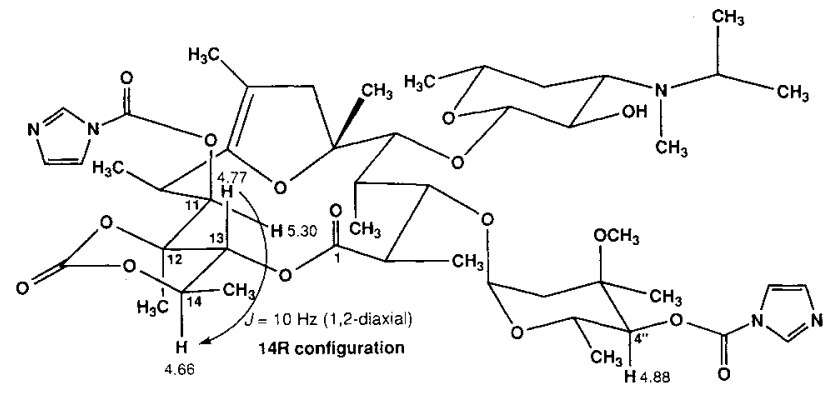

helpful. In the ${ }^{1} \mathrm{H}$ NMR spectrum of $4 \mathbf{a}, 13-\mathrm{H}$ was observed at $\delta 4.77 \mathrm{ppm}$ as a doublet $(J=10.1 \mathrm{~Hz})$ showing a coupling with $14-\mathrm{H}$ ( $\delta 4.66 \mathrm{ppm}$, double quartet, $J=10.1,6.3 \mathrm{~Hz})$. The coupling constant $(10.1 \mathrm{~Hz})$ indicated that two protons located in the 1,2-diaxial position on the 6-membered cyclic carbonate ring as shown in Fig. 3. This means the absolute configuration at $\mathrm{C} 14$ to be "R".

\section{Biological Activities}

The contractile activity ${ }^{10}$ in isolated rabbit duodenum (in vitro) and GMS activity ${ }^{10}$ (in vivo) of the obtained products are summarized in Table 3. All the metabolites showed activity comparable to that of the parent compound in the in vitro assay. On the other hand, except for 9, they exhibited 2- to 4-fold stronger GMS activity than 1 and 2 in vivo.

\section{Discussion}

Here we have described the microbial production of 14- and 15-hydroxyl derivatives of EM574 and EM523.
Table 4. Pharmacological activities of EM574, EM523 and their metabolites.

\begin{tabular}{lcc}
\hline Compound & $\begin{array}{c}\text { Contractile activity } \\
\left(\mathrm{EC}_{50}, \mathrm{nM}\right)\end{array}$ & $\begin{array}{c}\text { GMS activity } \\
\left(\mathrm{ED}_{200} \mathrm{mg} / \mathrm{kg}, i v\right)\end{array}$ \\
\hline EM574 (1) & 1.6 & 0.96 \\
EM574 P1 (3) & 2.6 & 0.38 \\
EM574 P2 (4) & 1.3 & 0.40 \\
EM574 P3 (7) & 2.5 & 0.21 \\
EM574 P4 (8) & 1.7 & 0.28 \\
EM523 (2) & 3.6 & 6.1 \\
EM523 P1 (5) & 2.7 & 4.0 \\
EM523 P2 (6) & 3.6 & 2.1 \\
EM523 P3 (9) & 4.8 & 15.5 \\
\hline
\end{tabular}

The bioactive metabolites $\mathbf{3}$ and $\mathbf{4}$ were detected in the plasma after oral administration of $\left[{ }^{14} \mathrm{C}\right]$-labeled 1 to dogs, ${ }^{11)}$ and therefore, the significance of the metabolites has become of greater interest. The main products, 14-hydroxyl derivatives (4 and 6), were obtained in sufficient amounts for further pharmaceutical investigation, while the yields for the 15-hydroxyl derivatives ( 3 and 5 ) were very low. The production utilized the three strains of actinomycetes for giving the metabolites in different yield from one another. It is quite interesting that such oxidative activity is observed in these strains belonging to the rare actinomycetes.

On the other hand, the $3 "$ - $O$-demethyl derivatives, $\mathrm{P} 3$ and $\mathrm{P} 4$, were isolated as unique microbial products. As the substrate for microbial conversion, 1 and $\mathbf{2}$ show some different characteristics. EM523 gave only a small amount of P1 and didn't give P4 even on a cultivation scale of 200 liters, while EM574 gave P1 P4 to some extent. EM574 and EM523 differ only in the $3^{\prime}-N$-alkyl group. This difference causes a slight change in the C14/15 position, but the alkyl group should affect the oxidation at the 3 "- $O$-position. It may be speculated that the alkyl group occupies the space near to the $3^{\prime \prime}$-O-methyl group as shown in Fig. 3. 
The absolute configuration at the $\mathrm{C} 14$ position of EM574 P2 was determined to be " $R$ " by converting the cyclic carbonate $\mathbf{4 a}$. As the metabolites of erythromycin derivatives in humans, 14-hydroxy-6- $O$-methylerythromycin $\mathrm{A}^{14)}$ has been reported. The stereochemistry at the $\mathrm{C} 14$ position of the major metabolite (M-5) was elucidated to be "R", and that of the minor one (M-6) was found to be "S". In the microbial (Mucor species) transformation of 6-O-methylerythromycin derivatives, ${ }^{15)}$ only (14R)-14-hydroxy-6-O-methylerythromycin A and B were isolated. These results partially agree with our results. We couldn't isolate "S"-derivatives having GMS activity in the microbial conversion, while the conversion using dog liver homogenates afforded the 14- and 15-hydroxyl derivatives in nearly the same yields. ${ }^{10)}$ This might mean that microorganisms, including actinomycetes and Mucor oxidize erythromycintype antibiotics stereo- and regio-selectively at the C14 position.

\section{Experimental}

\section{Measurement of Physico-chemical Data}

The UV spectra were measured at $23 \sim 28^{\circ} \mathrm{C}$ in methanol. The IR spectra were measured in $\mathrm{KBr}$ pellets using a Horiba FT-200 instrument. The SI-MS spectra were measured on a Hitachi M-80A instrument using glycerol as the matrix. The NMR spectra were measured in deuterochloroform. The $\delta$-values in the NMR spectra were recorded in ppm downfield from tetramethylsilane (TMS) as the external standard using a Bruker AC-300 spectrometer.

\section{Preparation of Seed Cultures of Actinomycetes}

Each actinomycete grown on a yeast extract-malt extract agar slant was inoculated into a 200 -ml Erlenmeyer flask containing a medium consisting of glucose $1 \%$, tryptone $1 \%$ and yeast extracts $0.6 \%(40 \mathrm{ml}, \mathrm{pH}$ 7.0) and shaken on a reciprocal shaker at $28^{\circ} \mathrm{C}$ for 24 hours. Five-milliliter portions of the resulting culture fluid were dispensed into test tubes and frozen at $-80^{\circ} \mathrm{C}$ as the working stock. The stock was thawed at room temperature, and a $1-\mathrm{ml}$ portion was transferred to a $200-\mathrm{ml}$ Erlenmeyer flask containing $40 \mathrm{ml}$ of the medium and shaken on a reciprocal shaker at $28^{\circ} \mathrm{C}$ for 24 hours to obtain the seed culture fluid.

Preparation of 3 and 4 by $N$. capreola (flask scale)

One-milliliter portions of the seed culture of $N$. capreola IFO 12847 were transferred to a $200-\mathrm{ml}$ Erlenmeyer flask containing $40 \mathrm{ml}$ of the medium and shaken on a reciprocal shaker at $28^{\circ} \mathrm{C}$ for 24 hours. Compound $1 \mathrm{~L}(6 \mathrm{mg} / \mathrm{ml}$ in water, $1.0 \mathrm{ml})$ was added to each flask and incubated at $28^{\circ} \mathrm{C}$ for 6 hours. The obtained culture broth (3.0 liters) was centrifuged at $4^{\circ} \mathrm{C}$ and $8000 \mathrm{rpm}$ for 10 minutes. The supernatant (2.8 liters) was adjusted to $\mathrm{pH} 7.0$ and subjected to Diaion HP-20 (20 $50 \mathrm{mesh}, 300 \mathrm{ml}$, Mitsubishi Chem. Ind., Japan) column chromatography. The desired fraction was washed with $50 \% \mathrm{MeOH}$ aq. (1.5 liters) and eluted with $80 \% \mathrm{MeOH}$ in $5 \mathrm{~mm} \mathrm{HCl}(900 \mathrm{ml})$. The eluate was neutralized, concentrated to $c a .200 \mathrm{ml}$, adjusted to $\mathrm{pH}$ 8.5 and extracted with EtOAc $(100 \mathrm{ml})$ three times. The EtOAc layers were combined, washed with water $(100 \mathrm{ml})$, dried over anhydrous sodium sulfate and evaporated to give a crude powder $(203 \mathrm{mg})$. This powder (200 mg) was subjected to silica gel column chromatography (E. Merck, silica gel 60, Art. 7734, 5.0 g) eluting with $\mathrm{MeOH}-\mathrm{CHCl}_{3}$. The fractions eluted with $\mathrm{MeOH}$ $\mathrm{CHCl}_{3} \quad(2: 98 \sim 5: 95$ and 5:95) were independently collected and concentrated to give crude powders of 4 $(111 \mathrm{mg})$ and $3(45 \mathrm{mg})$, respectively. The former was subjected to preparative HPLC (column: YMC-Pack, D-ODS-5, YMC, Japan, mobile phase: 55\% MeOH$0.02 \mathrm{M}$ phosphate buffer; $\mathrm{pH} 4.0$ ). The latter was subjected to prep. HPLC (28\% acetonitrile- $0.02 \mathrm{M}$ phosphate buffer). The fractions of 4 and 3 were independently collected, adjusted to $\mathrm{pH} \mathrm{7.4,} \mathrm{concentrated} \mathrm{to} \mathrm{about}$ $20 \mathrm{ml}$, adjusted to $\mathrm{pH} 8.5$ and extracted with EtOAc $(12 \mathrm{ml})$ three times. The organic layers were combined, washed with saline, dried over anhydrous sodium sulfate and evaporated to give powders of $4(43 \mathrm{mg})$ and 3 $(4.3 \mathrm{mg})$, respectively (total yield, $9.5 \%$ ).

UV: 4, $\lambda_{\max } 207 \mathrm{~nm}(\varepsilon 7700)$, IR: 4, 3460, 2970, 2940, $1740,1640,1460,1380,1330,1270,1170,1100,1060$, 1010, $940\left(\mathrm{~cm}^{-1}\right)$. SI-MS: $m / z 760\left(\mathrm{MH}^{+}\right), 602$ ( $\mathrm{MH}^{+}$-cladinose), Anal Calcd. for $\mathrm{C}_{39} \mathrm{H}_{69} \mathrm{NO}_{13}$. $0.5 \mathrm{H}_{2} \mathrm{O}: \mathrm{C} 60.92, \mathrm{H} 9.17, \mathrm{~N} 1.82$. Found: C 61.06, H $9.37, \mathrm{~N} 1.81$.

\section{Preparation of $\mathbf{4}$ by $A$. tolypophorus (flask scale)}

One-milliliter portions of the seed culture of A. tolypophorus IFO 13151 were transferred to a $200-\mathrm{ml}$ Erlenmeyer flask containing $40 \mathrm{ml}$ of the medium and shaken on a reciprocal shaker at $28^{\circ} \mathrm{C}$ for 48 hours. Compound $1 \mathrm{~L}(12 \mathrm{mg} / \mathrm{ml}$ in water, $1.0 \mathrm{ml})$ was added to each flask and incubated at $28^{\circ} \mathrm{C}$ for 20 hours. The obtained culture broth (3.0 liters) was treated in the same manner as described in the case of $N$. capreola to give a crude powder $(415 \mathrm{mg})$. This powder $(400 \mathrm{mg})$ was subjected to silica gel column chromatography $(10 \mathrm{~g})$ eluting with $\mathrm{MeOH}-\mathrm{CHCl}_{3}$. The fractions eluted with $\mathrm{MeOH}-\mathrm{CHCl}_{3}(2: 98)$ were collected and concentrated to give a crude powder of $4(218 \mathrm{mg})$. This powder was subjected to prep. HPLC (D-ODS-5, 57\% MeOH-0.02 M phosphate buffer; $\mathrm{pH} 4.0$ ). The fractions of 4 were collected, adjusted to $\mathrm{pH} 7.4$, concentrated to about $20 \mathrm{ml}$, adjusted to $\mathrm{pH} 8.5$ and extracted with EtOAc $(12 \mathrm{ml})$ three times. The organic layers were combined, washed with saline, dried over anhydrous sodium sulfate and evaporated to give a powder of $4(102 \mathrm{mg}$, yield $20 \%$ ).

Preparation of 4,7 and 8 by D. variesporum (flask scale) One-milliliter portions of the seed culture of D. variesporum IFO 14104 were transferred to a $200-\mathrm{ml}$ 
Erlenmeyer flask containing $40 \mathrm{ml}$ of the medium and shaken on a reciprocal shaker at $28^{\circ} \mathrm{C}$ for 24 hours. Compound $1 \mathrm{~L}(4 \mathrm{mg} / \mathrm{ml}$ in water, $1.0 \mathrm{ml})$ was added to each flask and incubated at $28^{\circ} \mathrm{C}$ for 24 hours. The obtained culture broth ( 9.0 liters) was treated in the same manner as described in the case of $N$. capreola to give a crude powder $(896 \mathrm{mg})$. This powder $(895 \mathrm{mg})$ was subjected to silica gel $(20 \mathrm{~g})$ column chromatography eluting with $\mathrm{MeOH}-\mathrm{CHCl}_{3}$ to give a mixture of 4,7 and 8 (468 mg). This mixture was subjected to prep. HPLC (D-ODS-5, solvent B) to give powders of 4 (43 mg), 8 (49 $\mathrm{mg}$ ) and crude 7 , respectively. The crude powder of 7 was purified by prep. HPLC ( $25 \%$ acetonitrile- $0.02 \mathrm{M}$ phosphate buffer, $\mathrm{pH} 4.0$ ) to give a powder of 7 (46 mg, total yield, 9.5\%).

UV: $7, \lambda_{\max } 206 \mathrm{~nm}(\varepsilon 8500)$, IR: $3460,2970,2940$, $1740,1640,1460,1380,1330,1270,1170,1110,1060$, 1010, $940\left(\mathrm{~cm}^{-1}\right)$. SI-MS: $m / z 746\left(\mathrm{MH}^{+}\right), 602\left(\mathrm{MH}^{+}-\right.$ cladinose), Anal Calcd. for $\mathrm{C}_{38} \mathrm{H}_{67} \mathrm{NO}_{13} \cdot 0.5 \mathrm{H}_{2} \mathrm{O}: \mathrm{C}$ 60.46, H 9.08, N 1.86. Found: C 60.48, H 9.21, N 1.84. 8; UV: $\lambda_{\max } 206 \mathrm{~nm}$ (c 7400), IR: 3490, 2970, 2940, 1730, $1640,1460,1380,1330,1270,1200,1160,1110,1060$, $1020 \mathrm{~cm}^{-1}$, SI-MS: $m / z 730\left(\mathrm{MH}^{+}\right), 586\left(\mathrm{MH}^{+}\right.$ cladinose), Anal Calcd. for $\mathrm{C}_{38} \mathrm{H}_{67} \mathrm{NO}_{12} \cdot 0.5 \mathrm{H}_{2} \mathrm{O}: \mathrm{C}$ 61.77, H 9.27, N 1.90. Found: C 61.86, H 9.43, N 1.90 .

\section{Preparation of 6 and 9 by $N$. capreola (flask scale)}

One-milliliter portions of the seed culture of $N$. capreola IFO 12847 were transferred to a $200-\mathrm{ml}$ Erlenmeyer flask containing $40 \mathrm{ml}$ of the medium and shaken on a reciprocal shaker at $28^{\circ} \mathrm{C}$ for 24 hours. Compound $2(8 \mathrm{mg} / \mathrm{ml}$ in $80 \% \mathrm{EtOH}, 0.5 \mathrm{ml})$ was added to the flask and incubated at $28^{\circ} \mathrm{C}$ for 4 hours. The obtained culture broth $(40 \mathrm{ml})$ was treated in the same manner as described in the case of $N$. capreola to give a crude powder $(4.0 \mathrm{mg})$. This powder was analyzed by HPLC (ODS; A-312, 25\% acetonitrile-0.02 M phosphate buffer; $\mathrm{pH} 4.0)$ and determined to contain $5(46 \mathrm{mg})$ and $6(2.0 \mathrm{mg})$. In another experiment, 9 was detected $(7 \mu \mathrm{g} / \mathrm{ml})$ in the culture broth obtained in the same manner.

Preparation of Seed Cultures for Large Scale Cultivation

The frozen stock was thawed at room temperature, and a 5-ml portion was transferred to a 2-liter Sakaguchi flask containing $500 \mathrm{ml}$ of the medium. The mixture was shaken on a reciprocal shaker at $28^{\circ} \mathrm{C}$ for 24 hours to obtain the seed culture fluid.

Preparation of 4,7 and 8 by D. variesporum (fermenter scale)

The above-mentioned seed culture fluid of $D$. variesporum (1.5 liters) was transferred to a 200 -liter stainless fermenter containing 120 liters of the above-mentioned medium. The mixture was cultivated at $28^{\circ} \mathrm{C}$ with aeration of 120 liter/minute and agitation of $180 \mathrm{rpm}$ for 24 hours. A solution of $1(16 \mathrm{mg} / \mathrm{ml}$ in $80 \% \mathrm{EtOH}$, $750 \mathrm{ml}$ ) was added to the tank and then incubated for 24 hours. The obtained culture broth (112 liters) was filtered with a filter aid Radiolite $(3 \mathrm{~kg}$, Showa Kagaku Kougyou, Japan). The filtrate (108 liters) was adjusted to $\mathrm{pH} 7.0$ and subjected to HP-20 (10 liters) column chromatography. The desired fraction was eluted with $80 \% \mathrm{MeOH}$ in $5 \mathrm{~mm} \mathrm{HCl}$ (30 liters). The eluate was neutralized, concentrated to $c a .7$ liters, adjusted to $\mathrm{pH}$ 8.5 and extracted with EtOAc ( 5 liters) twice. The EtOAc layers were combined, washed with water ( 5 liters), dried over anhydrous sodium sulfate and evaporated to give a crude powder $(4.3 \mathrm{~g})$. This powder was subjected to silica gel column chromatography (silica gel $60,100 \mathrm{~g}$ ) eluting with $\mathrm{MeOH}-\mathrm{CHCl}_{3}$. The fractions eluted with $\mathrm{MeOH}-\mathrm{CHCl}_{3} \quad(2: 98$ and $2: 98 \sim 5: 95)$ were independently collected and concentrated to give powder-I (972 mg) and powder-II (392 mg), respectively. Powder-I was purified by Sephadex LH-20 $(500 \mathrm{ml}$, Pharmacia, Sweden) column chromatography eluting with $\mathrm{MeOH}$ to give powder-III $(506 \mathrm{mg})$. Powder-II and -III were each subjected to prep. HPLC (ODS, YMC-Pack S-363 I-15) eluting with $30 \%$ acetonitrile- $0.02 \mathrm{M}$ phosphate buffer ( $\mathrm{pH} 4.0$ ). The fractions containing 4 and a mixture of 7 and $\mathbf{8}$ were independently collected, adjusted to $\mathrm{pH} 7.4$, concentrated, adjusted to $\mathrm{pH} 8.5$ and extracted with EtOAc three times. The organic layers were combined, washed with saline, dried over anhydrous sodium sulfate and evaporated to give powders of $4(104 \mathrm{mg})$ and a mixture of 7 and 8 . The mixture was subjected to prep. HPLC (D-ODS-5) eluting with $25 \%$ acetonitrile- $0.02 \mathrm{M}$ phosphate buffer ( $\mathrm{pH} \mathrm{4.0)}$ ). The fractions containing 7 and 8 were independently treated in the same manner to give powders of $7(129 \mathrm{mg})$ and $8(133 \mathrm{mg})$, respectively (total yield, ca. 3\%).

Preparation of 3, 4 and 7 by $N$. capreola (fermenter scale)

The seed culture fluid of $N$. capreola was transferred and cultured in the same manner as described in the case of D. variesporum for 24 hours. A solution of $1(16 \mathrm{mg} / \mathrm{ml}$ in $80 \% \mathrm{EtOH}, 750 \mathrm{ml}$ ) was added to the fermenter and then incubated for 6 hours. The obtained culture broth (120 liters) was treated in a manner similar to that described above to give a crude powder (6.1 g). This powder was subjected to silica gel column chromatography $(150 \mathrm{~g})$ eluting with $\mathrm{MeOH}-\mathrm{CHCl}_{3}$. The fractions eluted with $\mathrm{MeOH}-\mathrm{CHCl}_{3}(2: 98 \sim 5: 95$ and $5: 95)$ were independently collected and concentrated to give powder-I $(2.55 \mathrm{~g})$ and powder-II $(1.59 \mathrm{~g})$, respectively. Powder-I and -II were each purified by HP-20 (100 200 mesh, 100 and $50 \mathrm{ml}$ ) column chromatography eluting with $80 \% \mathrm{MeOH}$ in $5 \mathrm{~mm} \mathrm{HCl}$. The eluates were concentrated and extracted with EtOAc at $\mathrm{pH} 8.5$, and the organic layers were dried and evaporated to give powder-Ia (1.58 g) and $-\mathrm{IIa}(722 \mathrm{mg})$, respectively. Powder-Ia and -IIa were each subjected to prep. HPLC (ODS, YMC-Pack SH-363-15, S-15) eluting with 30\% 
and $26 \%$ acetonitrile- $0.02 \mathrm{M}$ phosphate buffer ( $\mathrm{pH} 4.0$ ) to give crude powders of $3(300 \mathrm{mg}), 4(534 \mathrm{mg})$ and 7 $(323 \mathrm{mg})$. These were each subjected to prep. HPLC (D-ODS-5 for 3, and SH-363-15 for 4, 7) eluting with solvent $\mathrm{C}, 55 \%$ and $54 \% \mathrm{MeOH}-0.02 \mathrm{M}$ phosphate buffer $(\mathrm{pH} 4.0)$ to give powders of $3(105 \mathrm{mg}), 4(338 \mathrm{mg})$ and $7(76 \mathrm{mg})$, respectively (total yield, ca. 4\%).

3; UV: $\lambda_{\max } 206 \mathrm{~nm}(\varepsilon 8500)$, IR: 3440, 2970, 2940, $1730,1640,1450,1380,1200,1170,1050,1010 \mathrm{~cm}^{-1}$, SI-MS: $m / z 760\left(\mathrm{MH}^{+}\right), 602\left(\mathrm{MH}^{+}\right.$-cladinose), Anal Calcd. for $\mathrm{C}_{39} \mathrm{H}_{69} \mathrm{NO}_{13} \cdot 0.5 \mathrm{H}_{2} \mathrm{O}: \mathrm{C} 60.92, \mathrm{H} 9.17, \mathrm{~N}$ 1.82. Found: C 60.63, H 9.15, N 1.78.

From another cultivation mixture (120 liters) incubated for 4 hours followed by an isolation procedure as described above, powders of 3 (149 $\mathrm{mg}), 4(1.40 \mathrm{~g})$ and $7(95 \mathrm{mg}$, total yield $13.4 \%$ ) were obtained.

From another cultivation mixture (1200 liters) incubated for 4 hours followed by an isolation procedure as described above, powders of $3(1.0 \mathrm{~g}), 4(13.2 \mathrm{~g})$ and 7 $(3.3 \mathrm{~g}$, total yield $14.3 \%$ ) were obtained.

Preparation of 5, 6 and 9 by $N$. capreola (fermenter scale)

The seed culture fluid of $N$. capreola was transferred and cultured in the same manner as described in the case of D. variesporum for 24 hours. A solution of $2(16 \mathrm{mg} / \mathrm{ml}$ in $80 \% \mathrm{EtOH}, 750 \mathrm{ml}$ ) was added to the fermenter and then incubated for 6 hours. The obtained culture broth (116 liters) was treated in a manner similar to that described above to give a crude powder $(9.0 \mathrm{~g})$. This powder was subjected to silica gel column chromatography $(200 \mathrm{~g})$ eluting with $\mathrm{MeOH}-\mathrm{CHCl}_{3}$. The fractions eluted with $\mathrm{MeOH}-\mathrm{CHCl}_{3}$ (2:98 and $\left.5: 98\right)$ were independently collected and concentrated to give powder-I $(2.9 \mathrm{~g})$ and powder-II $(1.68 \mathrm{~g})$, respectively. Powder-II was subjected to prep. HPLC (SH-363-15) eluting with $26 \%$ acetonitrile- $0.02 \mathrm{M}$ phosphate buffer $(\mathrm{pH} 4.0)$ to give crude powders of $5(80 \mathrm{mg})$ and 9 (783 mg). They were each subjected to prep. HPLC (D-ODS-5 for 5 and SH-363 for 9) eluting with 25\% acetonitrile and $52 \% \mathrm{MeOH}-0.02 \mathrm{M}$ phosphate buffer $(\mathrm{pH}$ 4.0) to give powders of $5(15 \mathrm{mg})$ and $9(200 \mathrm{mg})$, respectively. Powder-I was triturated from $\mathrm{MeOH}-\mathrm{Et}_{2} \mathrm{O}$ to give a powder of $6(812 \mathrm{mg}$, total yield, $8.5 \%)$.

5; UV: $\lambda_{\max } 209 \mathrm{~nm}(\varepsilon 8900)$, IR: 3450, 2970, 2940, $1720,1640,1450,1380,1200,1170,1050,1010 \mathrm{~cm}^{-1}$, SI-MS: $m / z 746\left(\mathrm{MH}^{+}\right), 588\left(\mathrm{MH}^{+}\right.$-cladinose), Anal Calcd. for $\mathrm{C}_{38} \mathrm{H}_{67} \mathrm{NO}_{13} \cdot 0.5 \mathrm{H}_{2} \mathrm{O}: \mathrm{C} 60.37, \mathrm{H} 9.20, \mathrm{~N}$ 1.80. Found: C 60.46, H 9.08, N 1.86. 6; UV: $\lambda_{\max } 207 \mathrm{~nm}$ (c 7600), IR: $3440,2980,2930,1740,1650,1450,1380$, 1340, 1280, 1170, 1050, 1010, $940 \mathrm{~cm}^{-1}$, SI-MS: $m / z 746$ $\left(\mathrm{MH}^{+}\right), 588\left(\mathrm{MH}^{+}\right.$-cladinose $)$, Anal Calcd. for $\mathrm{C}_{38} \mathrm{H}_{67} \mathrm{NO}_{13} \cdot \mathrm{H}_{2} \mathrm{O}: \mathrm{C} 59.74, \mathrm{H} 9.10, \mathrm{~N}$ 1.83. Found: $\mathrm{C}$ 59.83, H 9.14, N 1.73. 9; UV: $\lambda_{\max } 207 \mathrm{~nm}(\varepsilon 7700)$, IR: $3460,2980,2940,1740,1650,1460,1380,1330,1270$, $1170,1110,1050,1020,940 \mathrm{~cm}^{-1}$, SI-MS: $m / z 732$ $\left(\mathrm{MH}^{+}\right), 588\left(\mathrm{MH}^{+}\right.$-cladinose $)$, Anal Calcd. for $\mathrm{C}_{37} \mathrm{H}_{65} \mathrm{NO}_{13}$ : C 60.72, H 8.95, N 1.91. Found: C 60.32,

\section{H 9.01, N 1.97.}

From another cultivation mixture (120 liters) incubated for 4 hours followed by an isolation procedure as described above, powders of 5 (14 mg), 6 (4.16 g) and 9 (194 mg, total yield $34.0 \%$ ) were obtained.

Preparation of 9 by D. variesporum (fermenter scale) From another cultivation mixture (120 liters) incubated for 24 hours and followed by isolation procedure as described above was obtained a powder of 9 (383 $\mathrm{mg}$, yield $3.2 \%$ ).

\section{Preparation of Cyclic Carbonates $\mathbf{4 a}$ and $\mathbf{4 b}$}

To a stirred solution of $4(112 \mathrm{mg}, 0.148 \mathrm{mmol})$ in toluene $(5.6 \mathrm{ml})$ was added 1,1'-carbonyldiimidazole $\left(122 \mathrm{mg}, 5.0 \mathrm{eq}\right.$.). The mixture was heated at $80^{\circ} \mathrm{C}$ for 18 hours. The reaction mixture was diluted with EtOAc $(20 \mathrm{ml})$, washed with water $(10 \mathrm{ml})$ twice and then brine $(10 \mathrm{ml})$, dried over anhydrous sodium sulfate and evaporated to give a powder $(160 \mathrm{mg})$. This was subjected to silica gel chromatography eluting with a mixture of acetone and toluene. The fractions eluted with acetonetoluene $(3: 7 \sim 4: 6)$ were concentrated and subjected to prep. HPLC (ODS, YMC pack, D-ODS-5) eluting with $45 \%$ acetonitrile in phosphate buffer $(\mathrm{pH} \mathrm{3.0)}$. The fractions of $4 \mathbf{a}$ were collected, concentrated to $c a .10 \mathrm{ml}$ and extracted at $\mathrm{pH} 6.5$ with EtOAc $(10 \mathrm{ml})$ twice. The organic layers were combined, washed with water $(10 \mathrm{ml})$ twice and then brine $(10 \mathrm{ml})$, dried over anhydrous sodium sulfate and evaporated to give a powder of $\mathbf{4 a}$ ( $45 \mathrm{mg}$, yield $31 \%$ ). The fractions of pure $\mathbf{4 b}$ were treated in the same manner to give a powder of $\mathbf{4 b}(31 \mathrm{mg}$, yield $22 \%$ ).

4a; SI-MS: $m / z 974\left(\mathrm{MH}^{+}\right), 722\left(\mathrm{MH}^{+}\right.$- cladinose unit), Anal Calcd. for $\mathrm{C}_{48} \mathrm{H}_{71} \mathrm{~N}_{5} \mathrm{O}_{16} \cdot \mathrm{H}_{2} \mathrm{O}$ : C $58.11, \mathrm{H}$ 7.42, N 7.06. Found: C 58.06, H 7.29, N 6.62. ${ }^{13} \mathrm{C}$ NMR: $\delta 176.1(\mathrm{Q}), 148.9(\mathrm{Q}), 148.7(\mathrm{Q}), 148.4(\mathrm{Q}), 148.0(\mathrm{Q})$, $137.6(\mathrm{CH}), 136.9(\mathrm{CH}), 131.0(\mathrm{CH}), 130.8(\mathrm{CH}), 117.4$ $(\mathrm{CH}), 117.1(\mathrm{CH}), 103.8(\mathrm{Q}), 102.9(\mathrm{CH}), 95.3(\mathrm{CH}), 86.6$ (Q), 84.5 (Q), $83.4(\mathrm{CH}), 80.4(\mathrm{CH}), 77.3(\mathrm{CH}), 76.2$ $(\mathrm{CH}), 73.0(\mathrm{Q}), 71.2(\mathrm{CH}), 70.2(\mathrm{CH}), 70.1(\mathrm{CH}), 68.5$ $(\mathrm{CH}), 62.8(\mathrm{CH}), 62.7(\mathrm{CH}), 52.9(\mathrm{CH}), 49.7\left(\mathrm{CH}_{3}\right), 44.4$ (CH), 43.8(CH), 42.4( $\left(\mathrm{CH}_{2}\right), 35.0\left(\mathrm{CH}_{2}\right), 33.1\left(\mathrm{CH}_{2}\right), 31.1$ $\left(\mathrm{CH}_{3}\right), 30.9(\mathrm{CH}), 25.9\left(\mathrm{CH}_{3}\right), 21.5\left(\mathrm{CH}_{3}\right), 21.4\left(\mathrm{CH}_{3}\right)$, $21.2\left(\mathrm{CH}_{3}\right), 20.5\left(\mathrm{CH}_{3}\right), 18.9\left(\mathrm{CH}_{3}\right), 17.7\left(\mathrm{CH}_{3}\right), 16.9$ $\left(\mathrm{CH}_{3}\right), 15.2\left(\mathrm{CH}_{3}\right), 13.0\left(\mathrm{CH}_{3}\right), 11.7\left(\mathrm{CH}_{3}\right), 8.8\left(\mathrm{CH}_{3}\right)$. 4b; SI-MS: $m / z 974\left(\mathrm{MH}^{+}\right), 722\left(\mathrm{MH}^{+}\right.$- cladinose unit), Anal Caled. for $\mathrm{C}_{48} \mathrm{H}_{71} \mathrm{~N}_{5} \mathrm{O}_{16} \cdot \mathrm{H}_{2} \mathrm{O}$ : C 58.11, H 7.42, $\mathrm{N} 7.06$. Found: C 58.12, H 7.23, N 6.82. ${ }^{13} \mathrm{C}$ NMR: $\delta$ $176.1(\mathrm{Q}), 152.4(\mathrm{Q}), 148.7(\mathrm{Q}), 147.9(\mathrm{Q}), 147.2(\mathrm{Q})$, $137.3(\mathrm{CH}), 136.9(\mathrm{CH}), 130.9(\mathrm{CH}), 130.8(\mathrm{CH}), 117.3$ $(\mathrm{CH}), 117.1(\mathrm{CH}), 105.3(\mathrm{Q}), 103.1(\mathrm{CH}), 95.2(\mathrm{CH}), 87.7$ (Q), $84.3(\mathrm{Q}), 83.3(\mathrm{CH}), 82.8(\mathrm{CH}), 79.9(\mathrm{CH}), 76.6$ (CH), $74.0(\mathrm{CH}), 72.9(\mathrm{Q}), 72.4(\mathrm{CH}), 70.1(\mathrm{CH}), 68.6$ $(\mathrm{CH}), 62.9(\mathrm{CH}), 62.7(\mathrm{CH}), 52.9(\mathrm{CH}), 49.8\left(\mathrm{CH}_{3}\right), 43.6$ (CH), $43.5(\mathrm{CH}), 42.0\left(\mathrm{CH}_{2}\right), 35.0\left(\mathrm{CH}_{2}\right), 33.1\left(\mathrm{CH}_{2}\right)$, $31.7(\mathrm{CH}), 31.1\left(\mathrm{CH}_{3}\right), 25.7\left(\mathrm{CH}_{3}\right), 21.5\left(\mathrm{CH}_{3}\right), 21.3$ $\left(\mathrm{CH}_{3}\right), 21.2\left(\mathrm{CH}_{3}\right), 20.4\left(\mathrm{CH}_{3}\right), 17.8\left(\mathrm{CH}_{3}\right), 16.7\left(\mathrm{CH}_{3}\right)$, 
$15.7\left(\mathrm{CH}_{3}\right), 14.7\left(\mathrm{CH}_{3}\right), 12.6\left(\mathrm{CH}_{3}\right), 12.1\left(\mathrm{CH}_{3}\right), 8.6$ $\left(\mathrm{CH}_{3}\right)$.

\section{Acknowledgments}

The authors thank Drs. H. OKaZAKI and K. KrTANo for their continuous encouragement throughout this work. Thanks are also due to Mr. K. Matsushita for the biological assay and to Mr. Y. NAKano for his skillful assistance.

\section{References}

1) ITOH, Z; T. SuzukI, M. NAKaya, M. Inoue \& S. MITSUHASHI: Gastrointestinal motor-stimulating activity of macrolide antibiotics and analysis of their side effects on the canine gut. Antimicrob. Agents Chemother. 26: $863 \sim 869,1984$

2) Itoh, Z.; M. Nakaya, T. Suzuki, H. Arai \& K. WAKABAYASHI: Erythromycin mimics exogenous motilin in gastrointestinal contractile activity in the dog. Amer. J. Physiol. 247: G688 694, 1984

3) Tomomasa, T.; T. Kuroume, H. Arai, K WaKabayashi \& Z. ITOH: Erythromycin induces migrating motor complex in human gastrointestinal tract. Dig. Dis. Sci. 31: $157 \sim 161,1986$

4) PeEters, T. L.: Erythromycin and other macrolides as prokinetic agents. Gastroenterology 105: 1886 1899, 1993

5) Kondo, Y.; K. TORI, S. ŌMURA \& Z. ITOH: Erythromycin and its derivatives with motilin-like biological activities inhibit the specific binding of ${ }^{125} \mathrm{I}$-motilin to duodenal muscle. Biochem. Biophys. Res. Comm. 150: $877 \sim 882$, 1988

6) Peeters, T. L.; G. Matthiss, I. Depoortere, T. Cachet, J. Hoogmartens \& G. Vantrappen: Erythromycin is a motilin receptor agonist. Amer. J. Physiol. 257: G470 474, 1989

7) Satoh, M.; T. Sakal, I. Sano, K. Fujikura, H. Koyama, K. Ohshima, Z. IтOH \& S. Ōmura: EM574, an erythromycin derivative, is a potent motilin receptor agonist in human gastric antrum. J. Pharm. Exp. Ther. 271: $574 \sim 579,1994$

8) OMura, S.; K. Tsuzuki, T. Sunazuka, S. Marui, H. TOYODA, N. INATOMI \& Z. ITOH: Macrolides with gastrointestinal motor stimulating activity. J. Med. Chem. 30: $1941 \sim 1943,1987$

9) Tsuzuki, K.; T. Sunazuka, S. Marui, H. Toyoda, S. Ōmura, N. Inatomi \& Z. IтоH: Motilides, Macrolides with gastrointestinal motor stimulating activity $I$. $\mathrm{O}$-substituted and tertiary $\mathrm{N}$-substituted derivatives of 8,9-anhydroerythromycin A hemiacetal. Chem. Pharm. Bull. 37: $2687 \sim 2700,1989$

10) Funabashi, Y.; Y. Maeshiba, N. Inatomi, S. Tanayama, S. HARADA, Z. ITOH \& S. ŌMURA: Bioactive metabolites of EM574 and EM523, erythromycin derivatives having strong gastrointestinal moter stimulating activity. J. Antibiotics 49: 794 801, 1996

11) Harada, S.; Y. Funabashi, N. Inatomi, S. Tanida, S TANAYAma \& S. ŌMURA: Bioactive metabolites of a motilide (EM574), gastrointestinal motor stimulators in in vivo therapy. Abstracts of the International Conference on Microbial Secondary Metabolism (Interlaken) P3, 1994

12) Yasukochi, T.; H. Koga, Y. Sagara \& T. Horiuchi: Bacterial cytochrome P-450. Nippon Nogeikagaku Kaishi 66: 145 148, 1992

13) Jones, P. H.; T. J. Perum, E. K. Rowley \& E. J. Baker: Chemical modification of erythromycin antibiotics. 3. Synthesis of $4^{\prime \prime}$ and 11 esters of erythromycin A and B. J. Med. Chem. 15: 631 634, 1972

14) Adachi, T.; S. Morimoto, H. Kondoh, T. Nagate, Y. Watanabe \& $\mathrm{K}$. Sota: 14-Hydroxy-6-O-methylerythromycin $\mathrm{A}$, active metabolites of 6-O-methylerythromycin A on human. J. Antibiotics 41: 966 975, 1988

15) Sasaki, J.; K. Mizole, S. Morimoto, T. Adachi \& S. OMURA: Microbial transformation of 6-O-methylerythromycin derivatives. J. Antibiotics 41: 908 915, 1988 